\title{
ANNUAL WATER-RESOURCES REVIEW, WHITE SANDS MISSILE RANGE, NEW MEXICO, 1984
}

By R. R. Cruz

U.S. GEOLOGICAL SURVEY

Open-File Report 85-645

Prepared in cooperation with the

WHITE SANDS MISSILE RANGE

Albuquerque, New Mexico 
UNITED STATES DEPARTMENT OF THE INTERIOR

DONALD PAUL HODEL, Secretary

GEOLOGICAL SURVEY

Dallas L. Peck, Director

For additional information write to:

District Chief

U.S. Geological Survey

Water Resources Division

505 Marquette NW, Room 720

Albuquerque, New Mexico 87102
For sale by:

Open-File Services Section

Branch of Distribution

U.S. Geological Survey, MS 306

Box 25425, Denver Federal Center

Denver, Colorado 80225

(303) $236-7476$ 


\section{CONTENTS}

Page

Abstract $\ldots \ldots \ldots \ldots \ldots \ldots \ldots \ldots \ldots \ldots \ldots \ldots \ldots \ldots \ldots \ldots \ldots \ldots \ldots \ldots \ldots \ldots \ldots \ldots \ldots$

Introduction $\ldots \ldots \ldots \ldots \ldots \ldots \ldots \ldots \ldots \ldots \ldots \ldots \ldots \ldots \ldots \ldots \ldots \ldots \ldots \ldots \ldots \ldots \ldots$

Well-numbering system $\ldots \ldots \ldots \ldots \ldots \ldots \ldots \ldots \ldots \ldots \ldots \ldots \ldots \ldots \ldots \ldots . \ldots . \ldots$

Data-collection program ............................... 4

Ground-water pumpage ............................. 4

Water-level measurements in supply wells ................... 9

Water-level measurements in test wells, observation wells, and boreholes .................................... 13

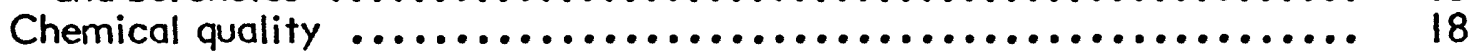

References $\ldots \ldots \ldots \ldots \ldots \ldots \ldots \ldots \ldots \ldots \ldots \ldots \ldots \ldots \ldots \ldots \ldots \ldots \ldots \ldots \ldots \ldots \ldots \ldots \ldots$

\section{ILLUSTRATIONS}

Figure 1. Map showing White Sands Missile Range and areas of hydrologic observations ........................... 2

2. Map showing location of supply wells, test wells, and boreholes in the Post Headquarters and adjacent areas .............. 6

3. Map showing location of wells in the Mockingbird Gap area

4. Map showing location of wells in the Rhodes Canyon and NW-30 areas

5. Map showing location of supply wells at the Stallion Range Center .................................

6. Hydrograph showing yearly pumpage from the Post Headquarters well field and water levels in test well T-8, 1970-84

7-9. Hydrographs showing water levels and specific conductance for period of record available in supply wells:

7. I0A, 11 , and $13 \ldots \ldots \ldots \ldots \ldots \ldots \ldots \ldots \ldots \ldots \ldots \ldots \ldots \ldots \ldots$

8. $\quad 16,17$, and $18 \ldots \ldots \ldots \ldots \ldots \ldots \ldots \ldots \ldots \ldots \ldots \ldots \ldots \ldots \ldots$

9. $19,20,21$, and 22 


\section{ILLUSTRATIONS - Concluded}

Page

Figure 10. Hydrographs showing water levels in test wells $T-7, T-8$, $T-10$, and $T-11$

11-13. Hydrographs showing monthly specific conductance, $\mathrm{pH}$, and pumpage for supply wells:

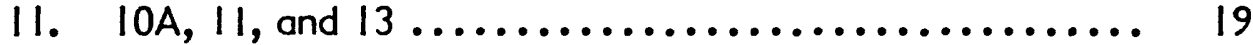

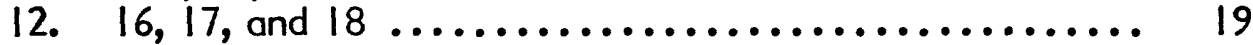

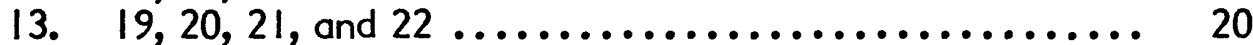

\section{TABLES}

Table I. Wells drilled on the White Sands Missile Range, 1984 .......... 5

2. Depth to water in supply wells, Post Headquarters and Range areas, 1984 ............................... g

3. Depth to water in test and observation wells, Post Headquarters and Range areas, 1984 .....................

4. Depth to water in boreholes, Post Headquarters and adjacent areas, 1984

5. Major chemical-constituent analyses of water from selected supply wells, Post Headquarters area, White Sands Missile Range, 1984

6. Major chemical-constituent and trace-element analyses of water from selected wells, White Sands Missile Range, 1984

7. Radiochemical analyses of water from selected supply wells, White Sands Missile Range, 1984

\section{CONVERSION FACTORS}

In this report, values for measurements are given in inch-pound units only. The following table contains factors for converting to International System (SI) units.

Multiply inch-pound units

foot

mile

gallon

acre-foot
By

0.3048

1.609

3.785

1,233
To obtain SI units

meter

kilometer

liter

cubic meter 


\title{
ANNUAL WATER-RESOURCES REVIEW, \\ WHITE SANDS MISSILE RANGE, \\ NEW MEXICO, 1984
}

\author{
By R. R. Cruz
}

\begin{abstract}
Hydrologic data were collected at White Sands Missile Range in 1984. The total ground-water withdrawal in 1984 was $685,275,000$ gallons. The Post Headquarters well field produced 650,821,000 gallons in 1984. Six new wells were drilled at White Sands Missile Range in 1984. Nineteen water samples were collected for major chemicalconstituent, trace-element, or radiochemical analysis in 1984. Depth-to-water measurements in the Post Headquarters supply wells showed seasonal fluctuations as well as continued long-term declines.
\end{abstract}

\section{INTRODUCTION}

This report presents water-resources data that were collected at White Sands Missile Range (fig. I) during 1984 by personnel of the U.S. Geological Survey and White Sands Missile Range. Ground-water pumpage, water-level measurements, chemicalquality data, and well-drilling data summarized in this report were obtained as a result of the continuing water-resources hydrologic-data-collection program sponsored by the Engineering and Housing Directorate, White Sands Missile Range.

This report is the seventeenth Annual Water-Resources Review prepared for the White Sands Missile Range. The 1968 report and subsequent annual reports are available for inspection at the District Office of the U.S. Geological Survey, Water Resources Division, Albuquerque, New Mexico. 


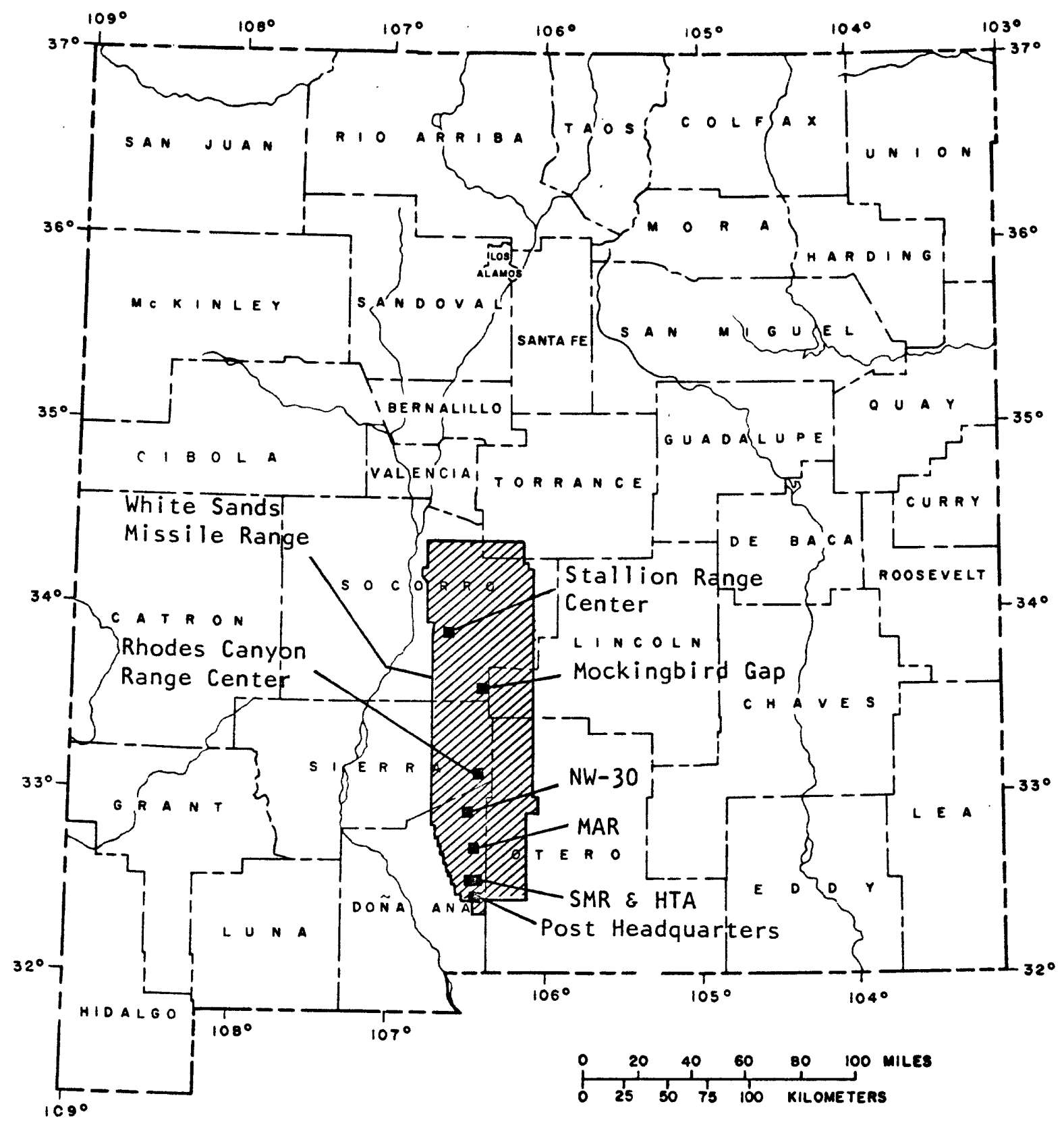

Figure 1.-- White Sands Missile Range and areas of hydrologic observations. 


\section{Well-Numbering System}

Wells are located according to the system of common subdivision of sectionized land used throughout the State by the U.S. Geological Survey. The number of each well consists of four segments separated by periods and locates the well's position to the nearest 10-acre tract of land. The segments denote, respectively, the township south of the New Mexico base line, the range east of the New Mexico principal meridian, the section, and the particular 10-acre tract within the section.

The fourth segment of the number consists of three digits denoting, respectively, the quarter section or approximate 160-acre tract, the quadrant (approximately 40 acres in size) of the quarter section, and the quadrant (approximately 10 acres in size) of the 40-acre tract in which the well is located. The system of numbering quarter sections and quadrants, which is done in reading order, as well as the usual numbering of sections within a township is shown below. For example, well 22S.4E.1.431 is located in the NW/4 of the SW/4 of the SE/4, section 1, Township 22 South, Range 4 East. If more than one well has the same location number, the letter "a" is assigned to the second well, the letter "b" to the third well and so on.

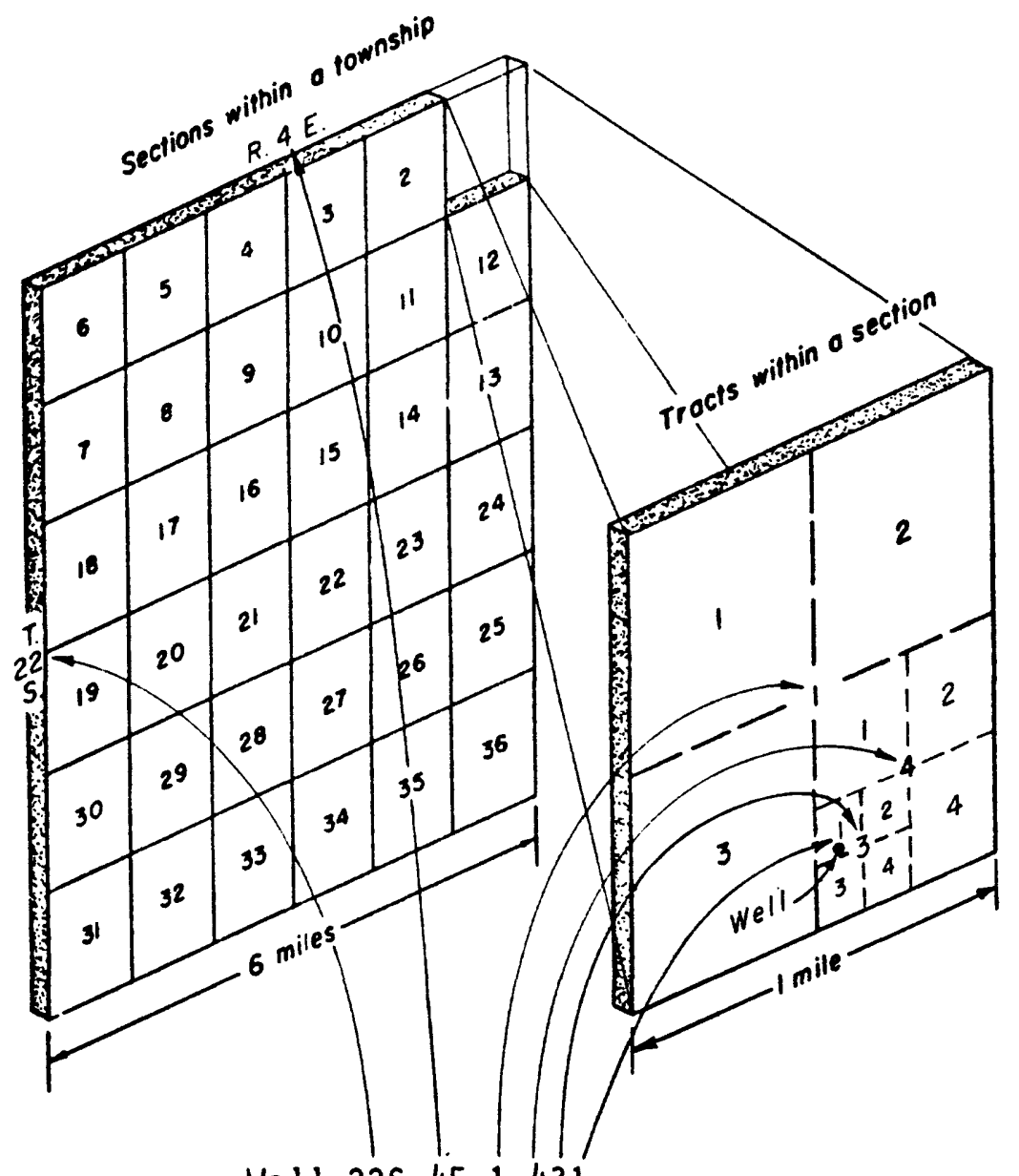

Well 22S.4E.1.431 


\section{DATA-COLLECTION PROGRAM}

The program to collect hydrologic data at the White Sands Missile Range has been continuous since 1953. The original program consisted of water-level measurements in five wells in the Post Headquarters area. Over the years, the program has expanded to keep up with the expansion of the White Sands Missile Range facilities. Six new wells were drilled on the White Sands Missile Range in 1984 (table 1). Currently the hydrologic data-collection program consists of semiannual depth-to-water measurements in 93 wells (tables 2-4) from Stallion Range Center on the north to about 6 miles south of the Post Headquarters area (figs. 1-5).

Ground-water withdrawal is measured at 17 supply wells in the Post Headquarters and Range areas. The total gallons pumped per year from the Post Headquarters well field for 1970-84 and a hydrograph of water levels in test well T-8 are shown in figure 6.

Nineteen water samples for analysis other than laboratory specific conductance and $\mathrm{pH}$ were collected in 1984 (tables 5-7). Seven water samples were analyzed for major chemical constituents (table 5), five for major chemical constituents and trace elements (table 6), and seven for radiochemicals (table 7). Water-level data and specific conductance for water from the Post Headquarters supply wells for the period of record are shown in figures 7,8 , and 9.

\section{Ground-Water Pumpage}

Total ground-water pumpage* at the White Sands Missile Range in 1984 was $685,275,000$ gallons. The Post Headquarters well field produced $650,821,000$ gallons, the Hazardous Test Area well (HTA-1) produced 145,000 gallons, the Small Missile Range well (SMR-1) produced 947,800 gallons, the Multifunction Array Radar wells (MAR-I and MAR-2) produced 23,701,700 gallons, and the Stallion Range Center wells (SRC-I and SRC-2) produced 9,659,000 gallons in 1984. Total pumpage was 28.3 million gallons less in 1984 than in 1983.

*The pumpage figures used in this report are to be considered as preliminary figures and may be subject to revision. 


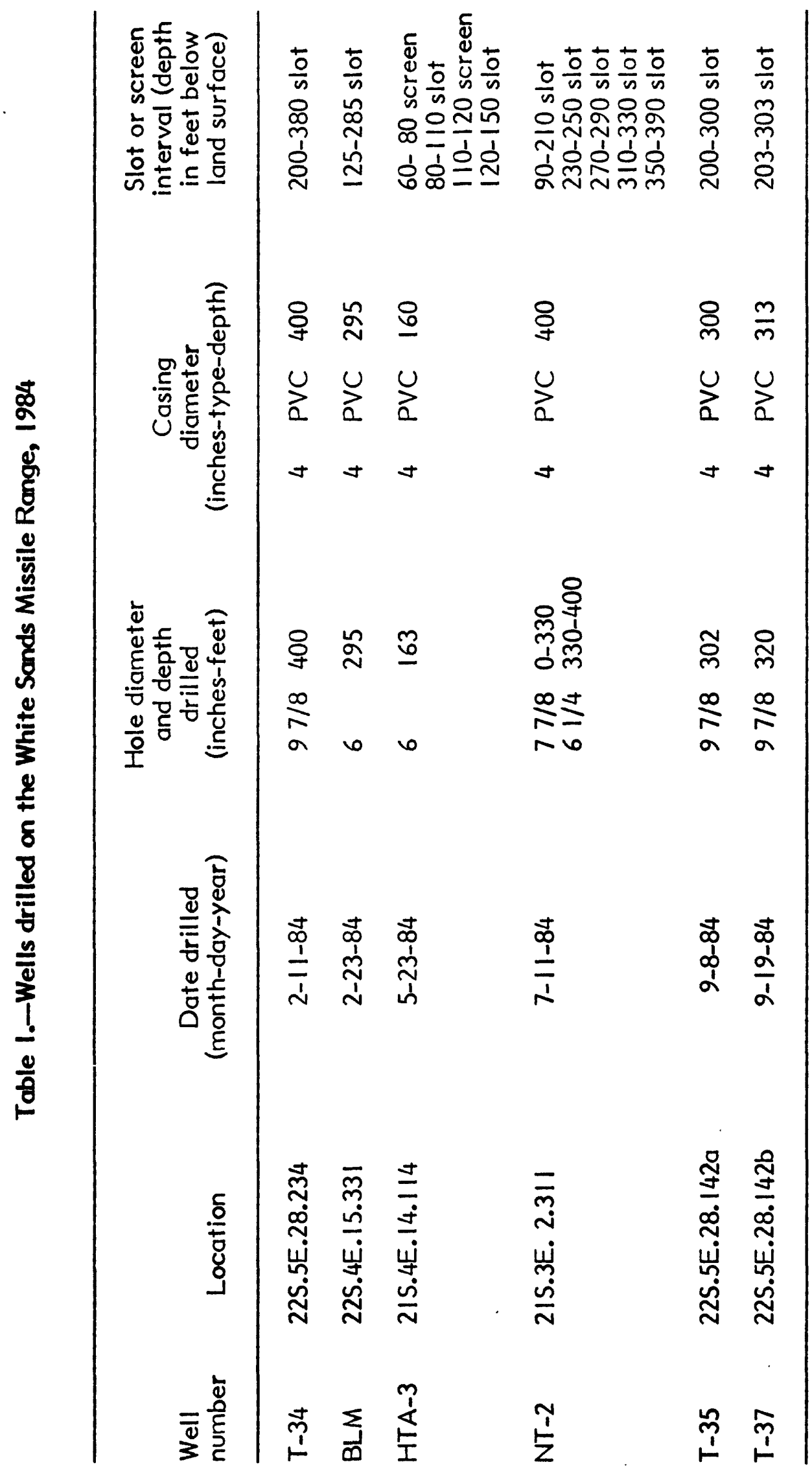




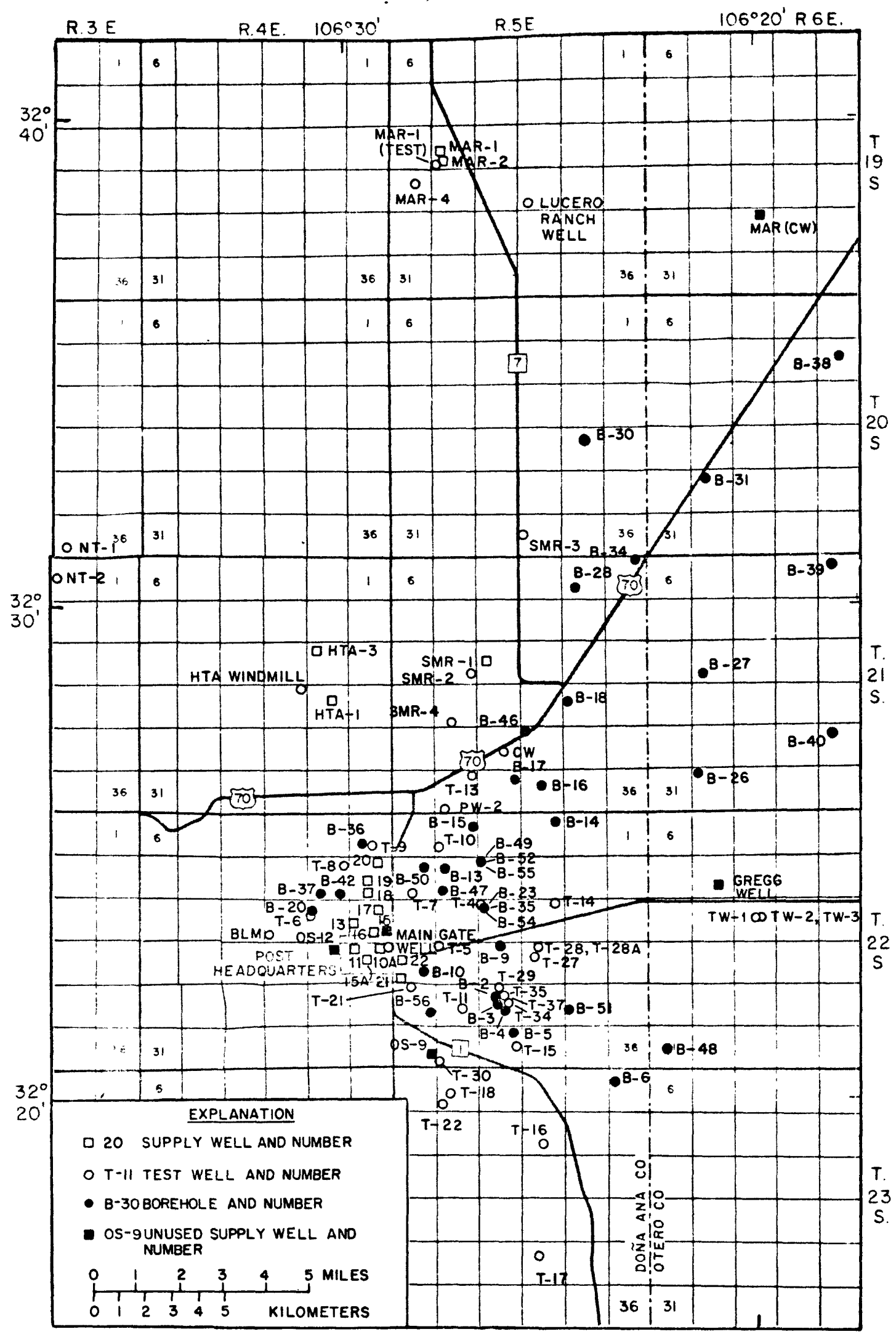

Figure 2.--Location of supply wells, test wells, and boreholes in the Post Headquarters and adjacent areas. 


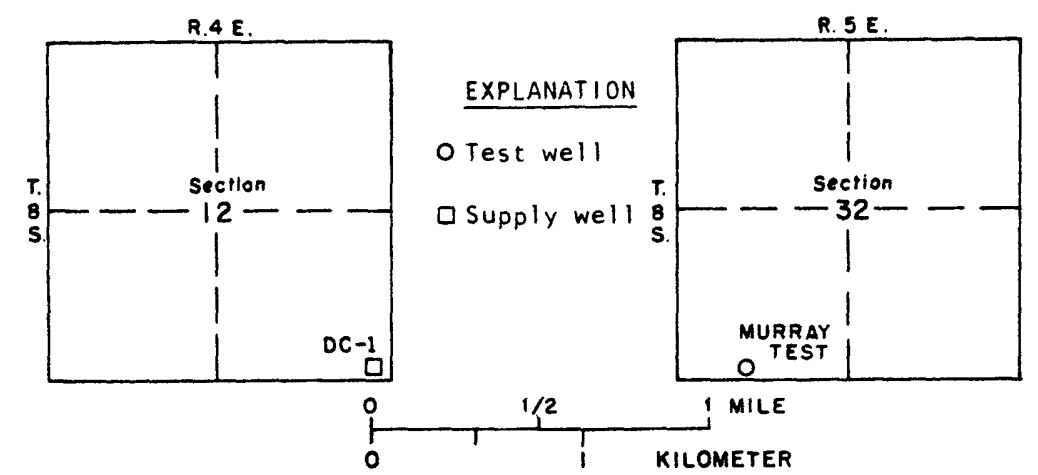

Figure 3.--Location of wells in the Mockingbird Gap area'.
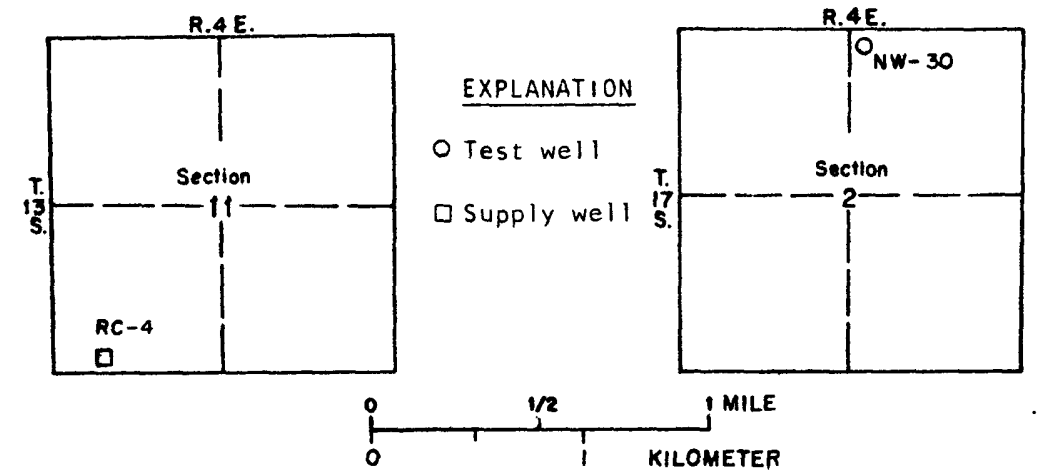

Figure 4.--Location of wells in the Rhodes Canyon and NW-30 areas.

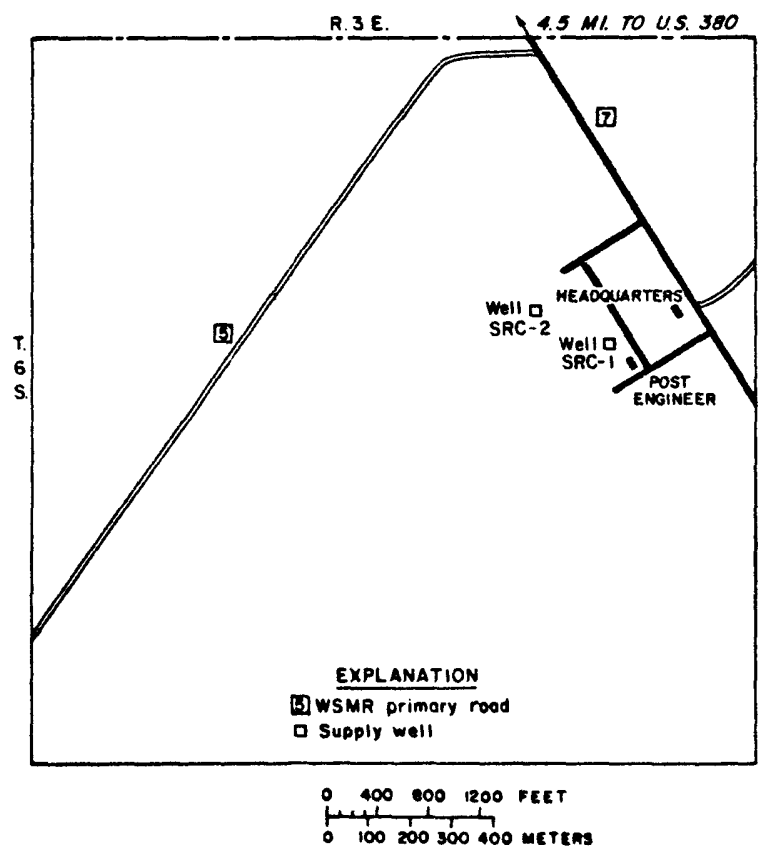

Figure 5.--Location of supply wells at the Stallion Range Center. 

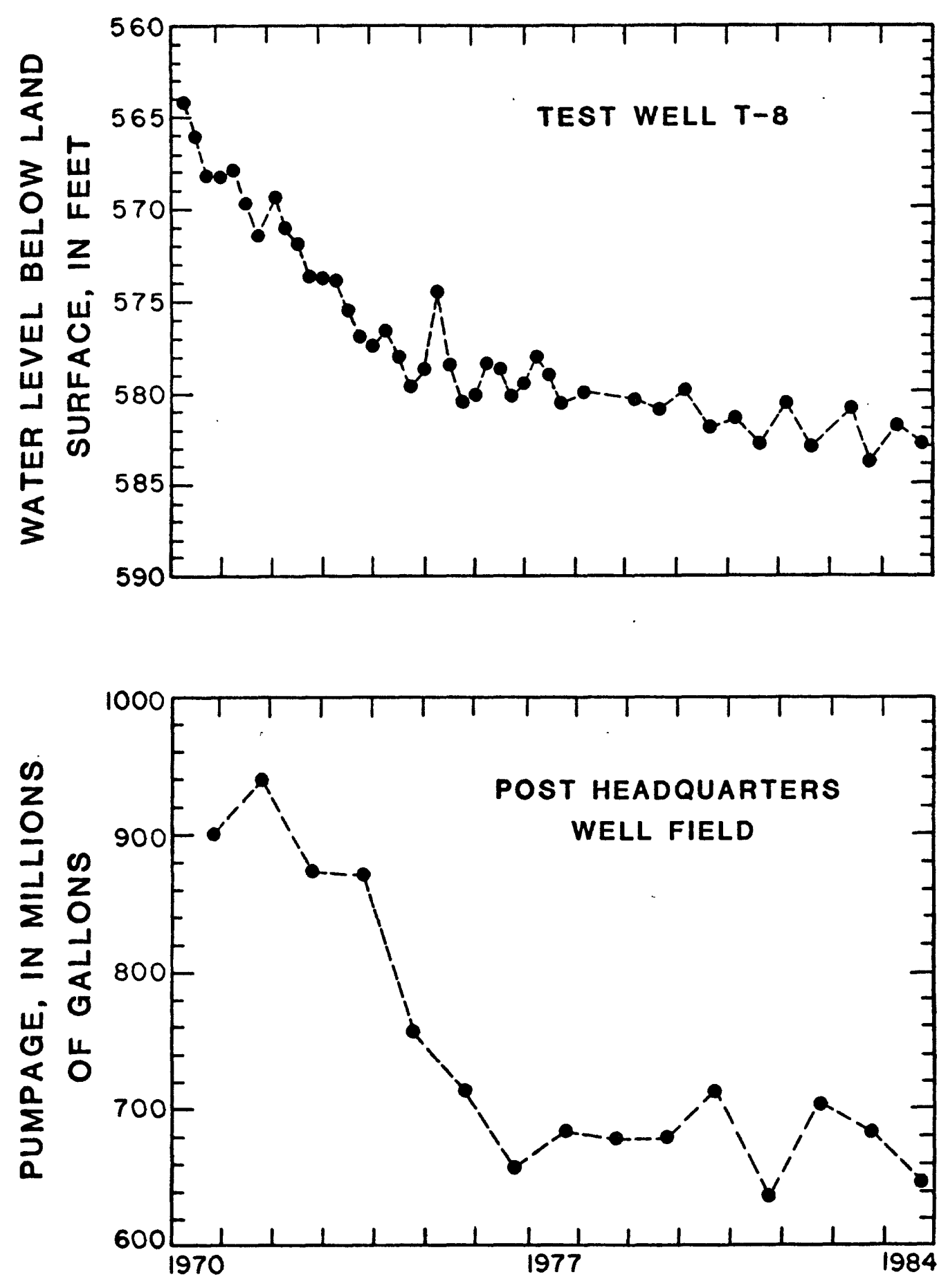

Figure 6.--Yearly pumpage from the Post Headquarters well field and water levels in test well T-8, 1970-84. 
Water-Level Measurements in Supply Wells

Semiannual depth-to-water measurements were made in 10 supply wells in the Post Headquarters area and 3 supply wells in the Range areas (table 2). Hydrographs of water levels in the 10 supply wells in the Post Headquarters well field for period of record available are shown in figures 7 through 9. The Small Missile Range (SMR-1) and the Multifunction Array Radar (MAR-I and 2) supply wells were not measured semiannually in 1984 because of continued pumping. SMR-1 and MAR-2 have one measurement each and MAR-1 does not have any. The two 1984 depth-to-water measurements in these wells are comparable with the 1983 measurements.

Table 2.-Depth to water in supply wells, Post Headquarters and Range areas, 1984

\begin{tabular}{|c|c|c|c|}
\hline $\begin{array}{l}\text { Well } \\
\text { number }\end{array}$ & Location & $\begin{array}{l}\text { Winter } 1984 \\
\text { (feet below } \\
\text { land surface) }\end{array}$ & $\begin{array}{l}\text { Summer } 1984 \\
\text { (feet below } \\
\text { land surface) }\end{array}$ \\
\hline $\begin{array}{l}10 A \\
11 \\
13 \\
16 \\
17\end{array}$ & $\begin{array}{l}22 S .4 E .24 .212 a \\
22 S .4 E .24 .112 \\
22 S .4 E .13 .311 \\
22 S .4 E .13 .432 \\
22 S .4 E .13 .241\end{array}$ & $\begin{array}{l}427.55 \\
402.00^{*} \\
-- \\
446.00^{*} \\
443.20\end{array}$ & $\begin{array}{l}431.20 \\
346.00^{*} \\
300.00^{*} \\
460.00^{*} \\
451.86\end{array}$ \\
\hline $\begin{array}{l}18 \\
19 \\
20 \\
21 \\
22\end{array}$ & $\begin{array}{l}22 \mathrm{~S} .4 \mathrm{E} .12 .434 \\
22 \mathrm{~S} .4 \mathrm{E} .12 .414 \\
22 \mathrm{~S} .4 \mathrm{E} .12 .214 \\
22 \mathrm{~S} .5 \mathrm{E} .19 .323 \\
22 \mathrm{~S} .5 \mathrm{E} .19 .141\end{array}$ & $\begin{array}{l}428.44 \\
454.45 \\
517.85 \\
357.04 \\
377.12\end{array}$ & $\begin{array}{l}438.83 \\
460.03 \\
519.35 \\
359.22 \\
381.12\end{array}$ \\
\hline $\begin{array}{l}\text { HTA-1 } \\
\text { SMR-1 } \\
\text { MAR-2 }\end{array}$ & $\begin{array}{l}21 S .4 E .23 .233 \\
21 S .5 E .16 .132 \\
19 S .5 E .17 .334\end{array}$ & $\begin{array}{r}65.99 \\
297.75 \\
-\end{array}$ & $\begin{array}{c}66.65 \\
-- \\
221.86\end{array}$ \\
\hline $\begin{array}{l}\text { SRC-1 } \\
\text { SRC-2 }\end{array}$ & $\begin{array}{l}\text { 6S.3E.05.232 } \\
6 \text { 6S.3E.05.234 }\end{array}$ & $\begin{array}{l}211.40 \\
215.20\end{array}$ & $\begin{array}{l}210.00 \\
214.60\end{array}$ \\
\hline
\end{tabular}

* Air line reading 
SUPPLY WELL 10A
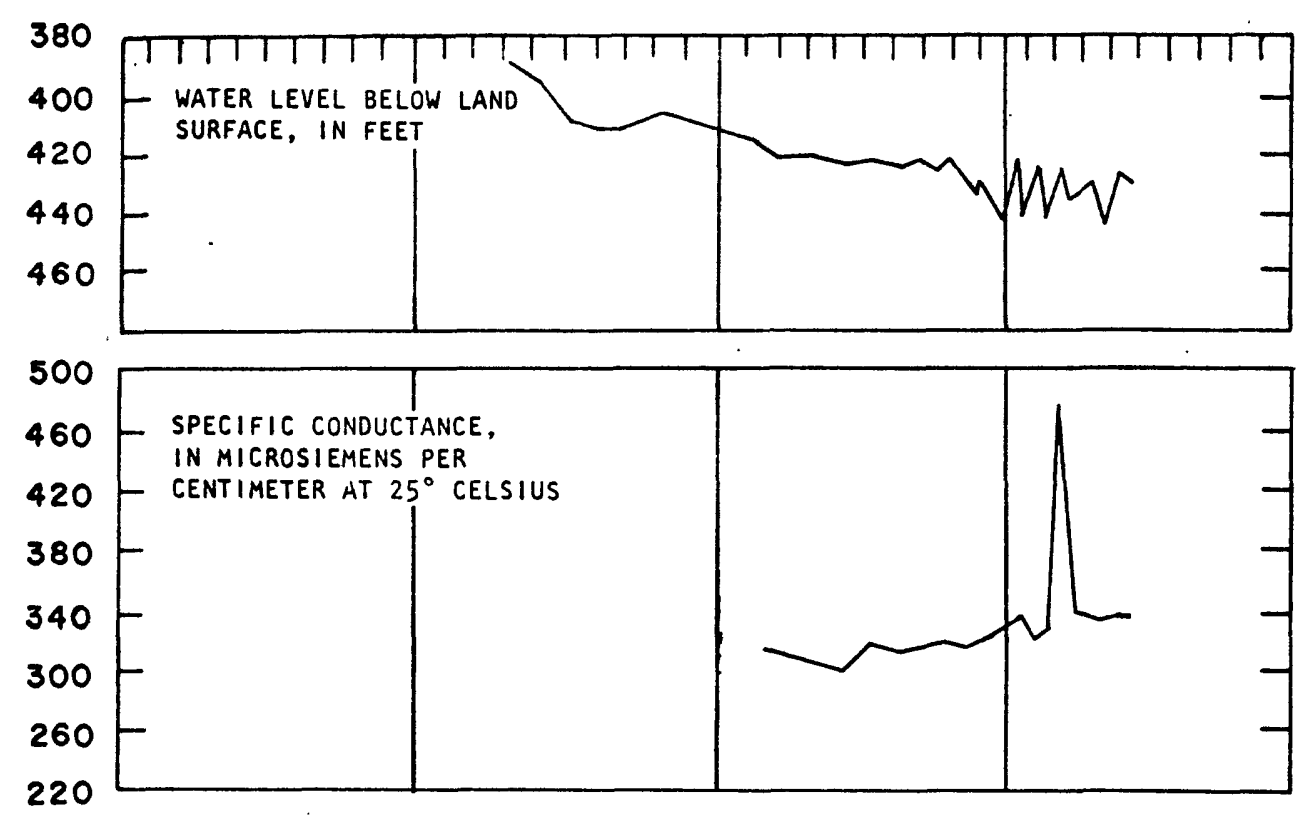

SUPPLY WELL 11
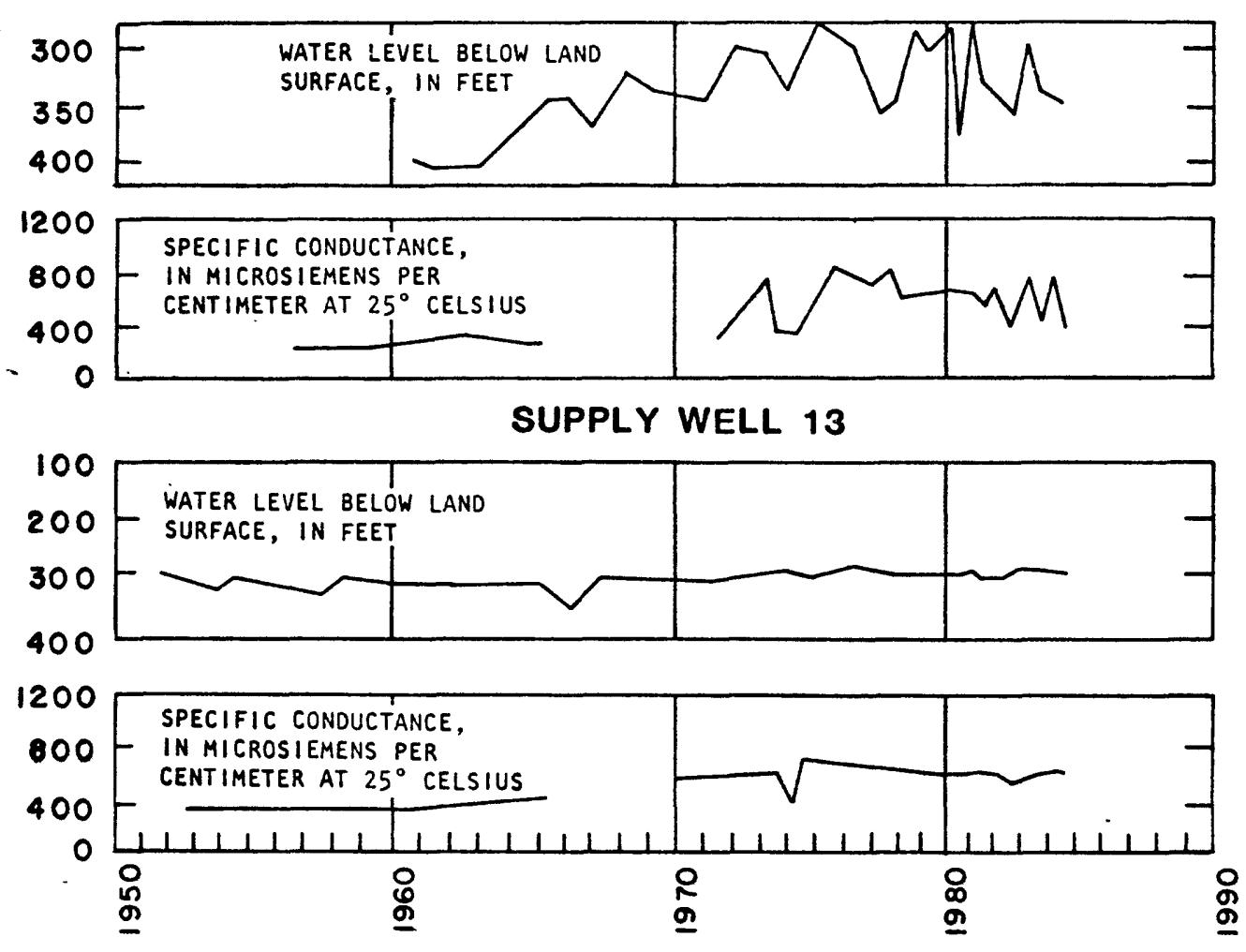

Figure 7.--Water levels and specific conductance for period of record available in supply wells 10A, 11, and 13 . 
SUPPLY WELL 16
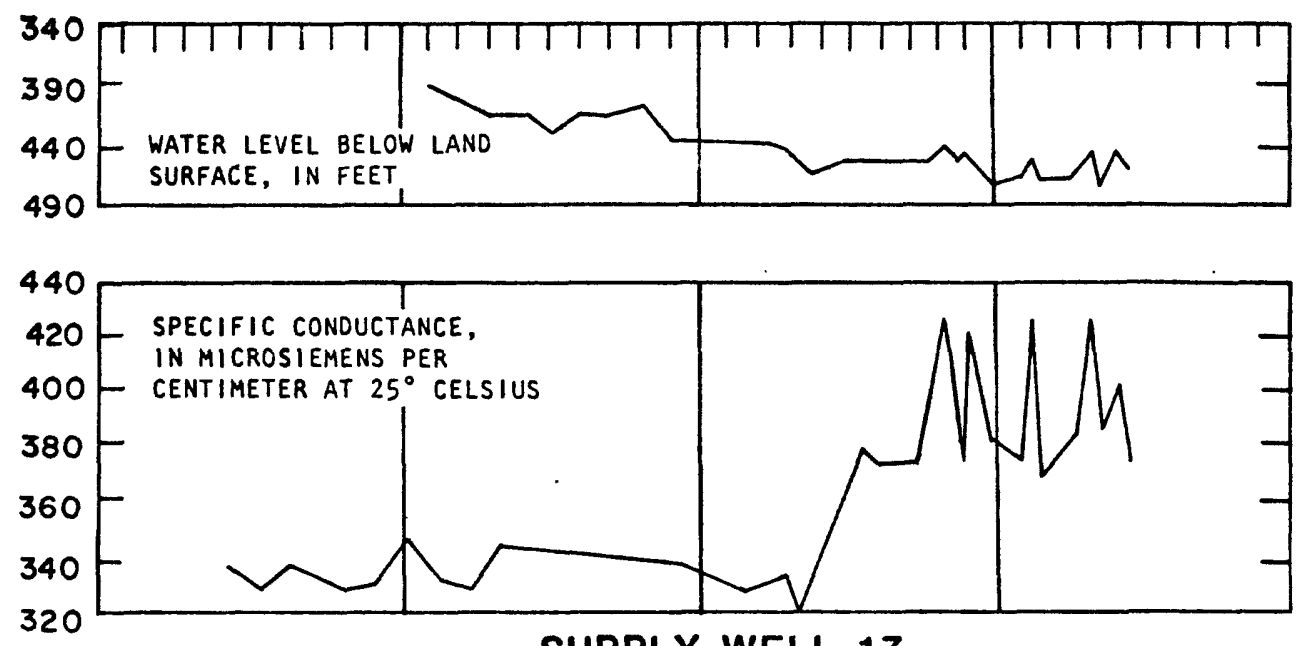

SUPPLY WELL 17
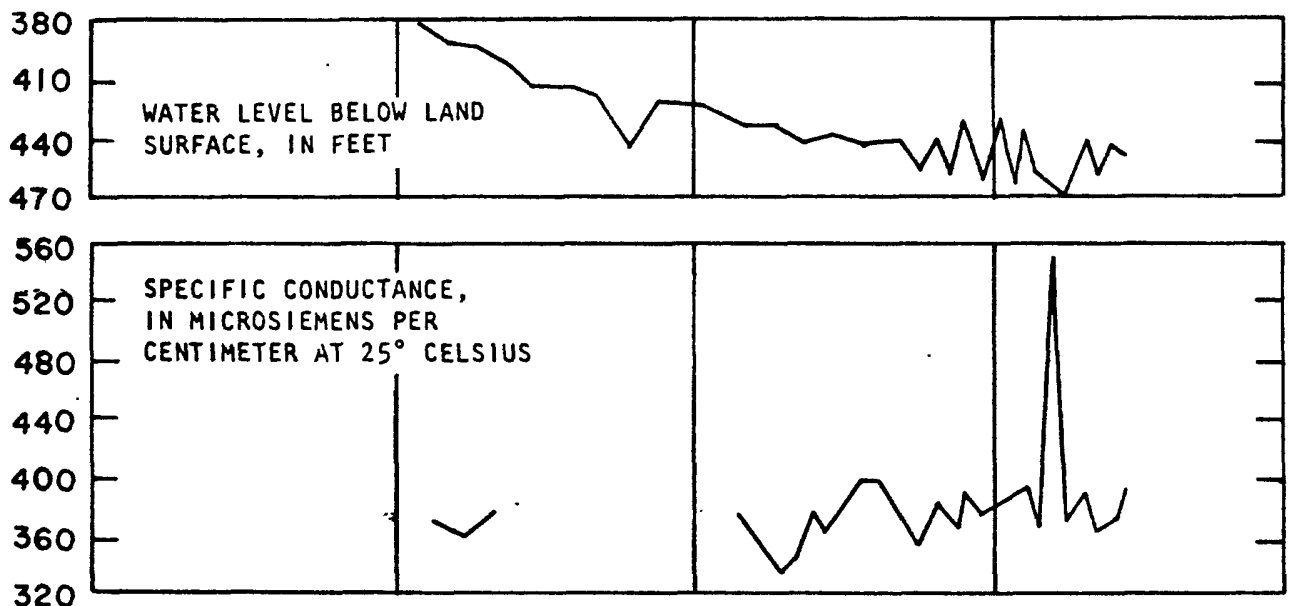

SUPPLY WELL 18
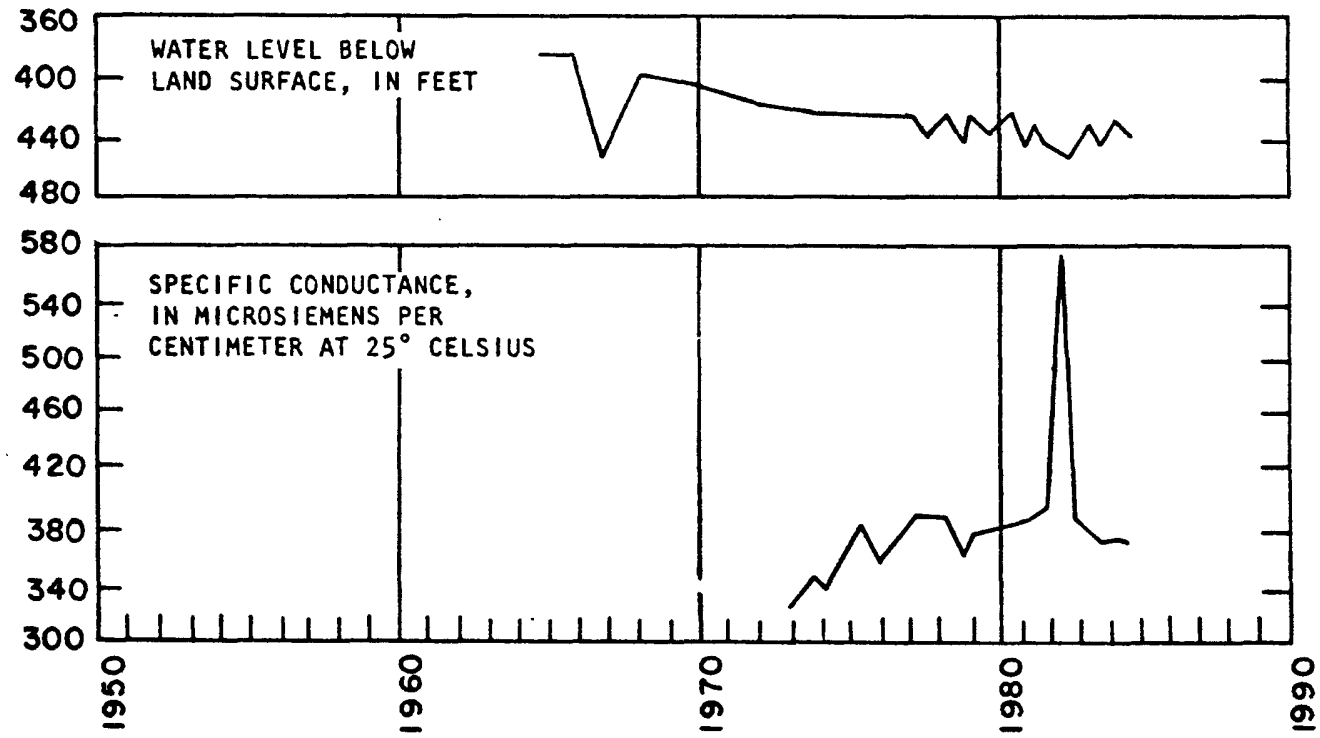

Figure 8.--Water levels and specific conductance for period of record available in supply wells 16, 17, and 18 . 
SUPPLY WELL 18

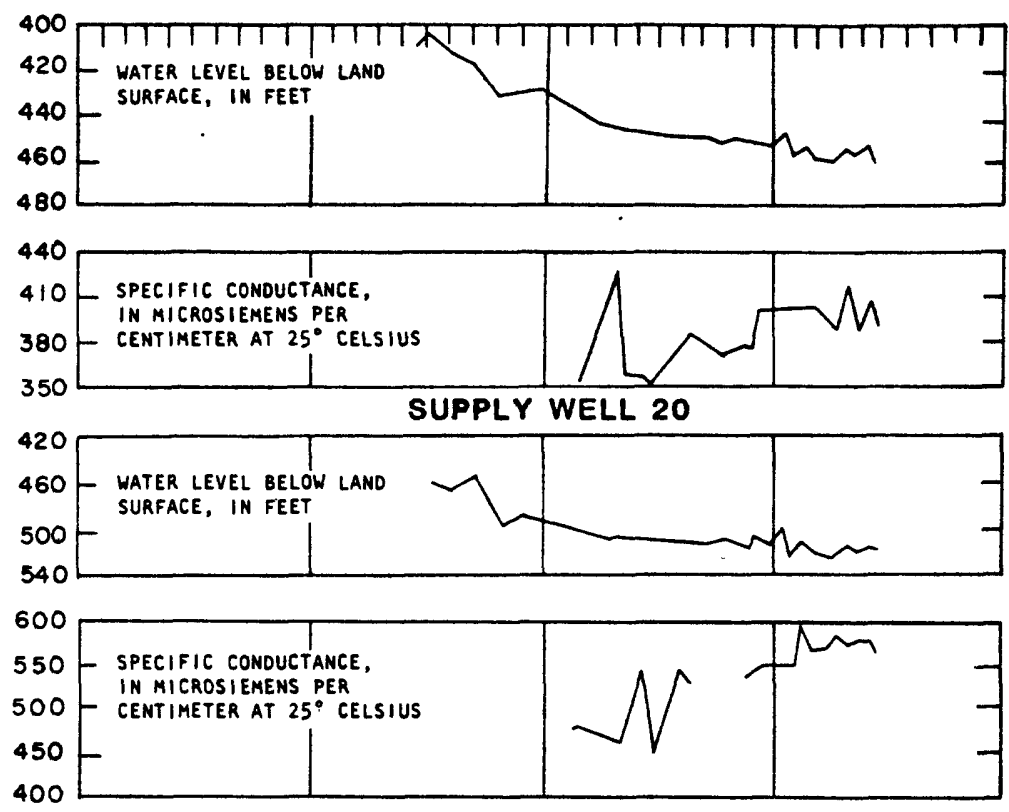

SUPPLY WELL 21
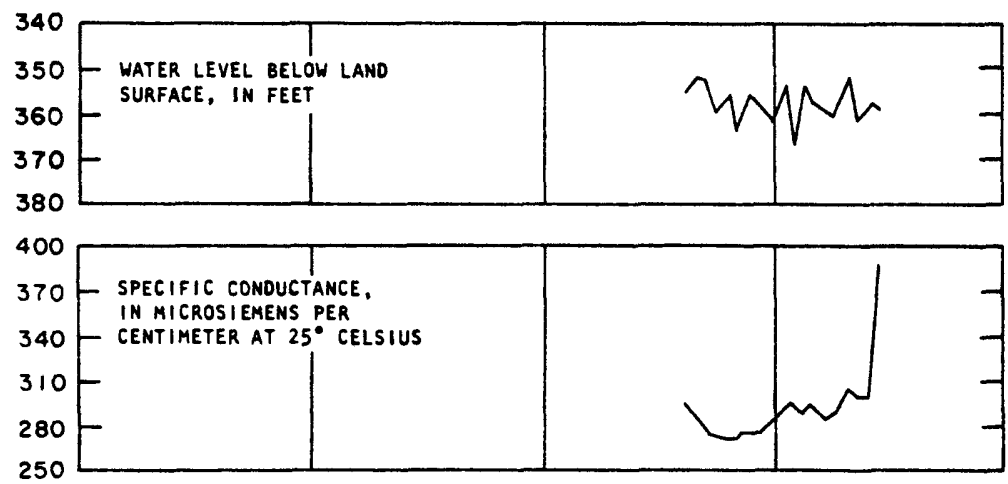

SUPPLY WELL 22
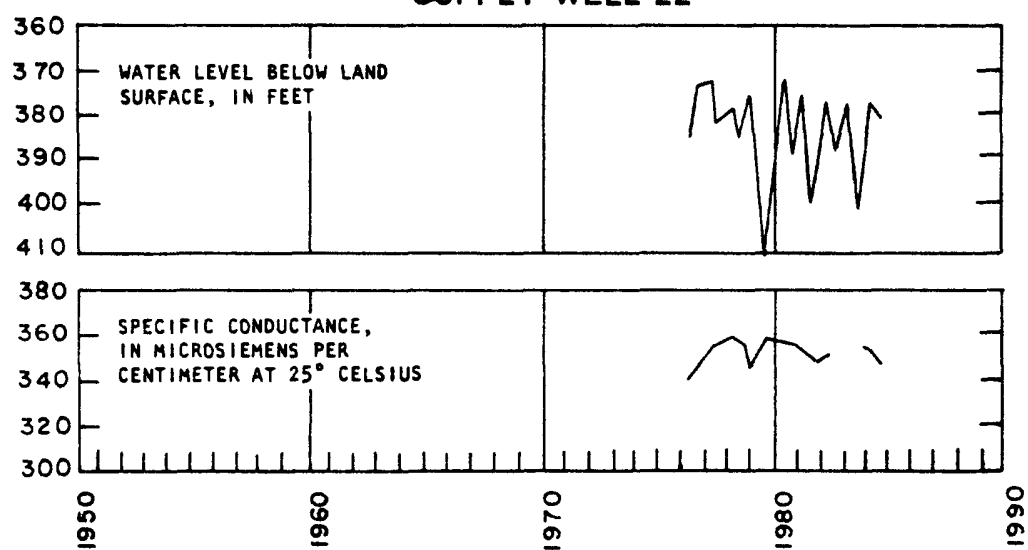

Figure 9.-- Water levels and specific conductance for period of record available in supply wells 19, 20, 21 , and 22 . 
Water-Level Measurements in Test Wells, Observation Wells, and Boreholes

Semiannual depth-to-water measurements were made in 41 test and observation wells in 1984 (table 3). Four of the test wells (T-7, T-8, T-10, and T-11) in the Post Headquarters area are equipped with continuous water-level recorders; hydrographs of water levels in these wells are shown in figure 10. The seasonal fluctuations ranged from a 0.68-foot water-level rise in test well T-6 to a 10.79-foot water-level decline in old supply well 15 in 1984 (table 3). Test well T-6 is about I mile west of the Post Headquarters well field and OS-15 is about in the center of the well field.

Table 3.-Depth to water in test and observation wells, Post Headquarters and Range areas, 1984

\begin{tabular}{llll}
\hline $\begin{array}{l}\text { Wel! } \\
\text { number }\end{array}$ & Location & $\begin{array}{l}\text { Winter 1984 } \\
\text { (feet below } \\
\text { land surface) }\end{array}$ & $\begin{array}{l}\text { Summer 1984 } \\
\text { (feet below } \\
\text { land surface) }\end{array}$ \\
\hline T-4 & 22S.5E.16.111 & 226.76 & 226.80 \\
T-5 & 22S.5E.20.111 & 277.03 & 277.11 \\
T-6 & 22S.4E.14.133 & 193.71 & 193.03 \\
T-7 & 22S.5E.07.342 & 362.30 & 371.95 \\
T-8 & 22S.4E.11.224 & 581.71 & 583.05 \\
T-9 & 22S.4E.01.431 & 375.18 & 374.56 \\
T-10 & 22S.5E.05.313 & 273.40 & 273.82 \\
T-11 & 22S.5E.29.412 & 272.04 & 272.29 \\
T-13 & 21S.5E.32.222 & 213.03 & 213.39 \\
T-14 & 22S.5E.15.221 & 132.33 & 132.26 \\
T-15 & 22S.5E.33.244 & 179.58 & 179.55 \\
T-16 & 23S.5E.10.413 & 183.79 & 183.11 \\
T-17 & 23S.5E.27.142 & 242.44 & 242.35 \\
T-18 & 23S.5E.05.321 & 238.33 & 238.27 \\
OS-9 & 22S.5E.31.424 & 244.33 & 244.51 \\
OS-12 & 22S.4E.23.214 & 233.39 & 234.86 \\
OS-15 & 22S.4E.13.424 & 423.80 & 434.59 \\
Gregg & 22S.6E.08.414 & 214.33 & 214.54 \\
HTA (wm) & 21S.4E.22.222 & 42.99 & 43.60 \\
SMR-2 & 21S.5E.17.424 & 320.85 & 320.90 \\
SMR-3 & 20S.5E.34.133 & 295.75 & 300.58 \\
SMR-4 & 21S.5E.20.344 & 289.21 & 289.29 \\
MAR-1 & 19S.5E.17.333 & 222.23 & 223.13 \\
(test) & 19S.5E.19.231 & 304.25 & 304.46 \\
MAR-4 & & 213.17 \\
NW30-1 & 17S.4E.02.211 & - & \\
& & &
\end{tabular}


Table 3.- Depth to water in test and observation wells, Post Headquarters and Range areas, 1984 - Concluded

\begin{tabular}{llll}
\hline $\begin{array}{l}\text { Well } \\
\text { number }\end{array}$ & Location & $\begin{array}{l}\text { Winter 1984 } \\
\text { (feet below } \\
\text { land surface) }\end{array}$ & $\begin{array}{l}\text { Summer 1984 } \\
\text { (feet below } \\
\text { land surface) }\end{array}$ \\
\hline $\begin{array}{l}\text { Murray } \\
\text { Lucero }\end{array}$ & 8S.5E.32.334 & 177.39 & 177.53 \\
Ranch & 19S.5E.22.334 & 171.20 & 171.17 \\
CW & 21S.5E.28.411 & 154.15 & 154.44 \\
T-21 & 22S.5E.30.122 & 316.89 & 317.55 \\
T-22 & 23S.5E.05.144 & 189.48 & 189.40 \\
T-27 & 22S.5E.22.141 & 162.60 & 162.49 \\
T-28A & 22S.5E.22.122a & 155.23 & 155.19 \\
T-29 & 22S.5E.28.122 & 149.87 & 152.23 \\
T-30 & 22S.5E.32.334 & 213.98 & 214.18 \\
T-34 & 22S.5E.28.234 & 187.28 & 187.38 \\
TW-1 & 22S.6E.16.233 & 229.13 & 229.29 \\
TW-2 & 22S.6E.16.234 & 235.59 & 235.80 \\
TW-3 & 22S.6E.16.234a & -5 & 232.40 \\
NT-1 & $20 S .3 E .35 .341$ & 126.88 & 130.63 \\
BLM & 22S.4E.15.331 & 65.79 & 65.77 \\
DC-1 & 8S.4E.02.444 & 255.18 & 255.03 \\
& & &
\end{tabular}




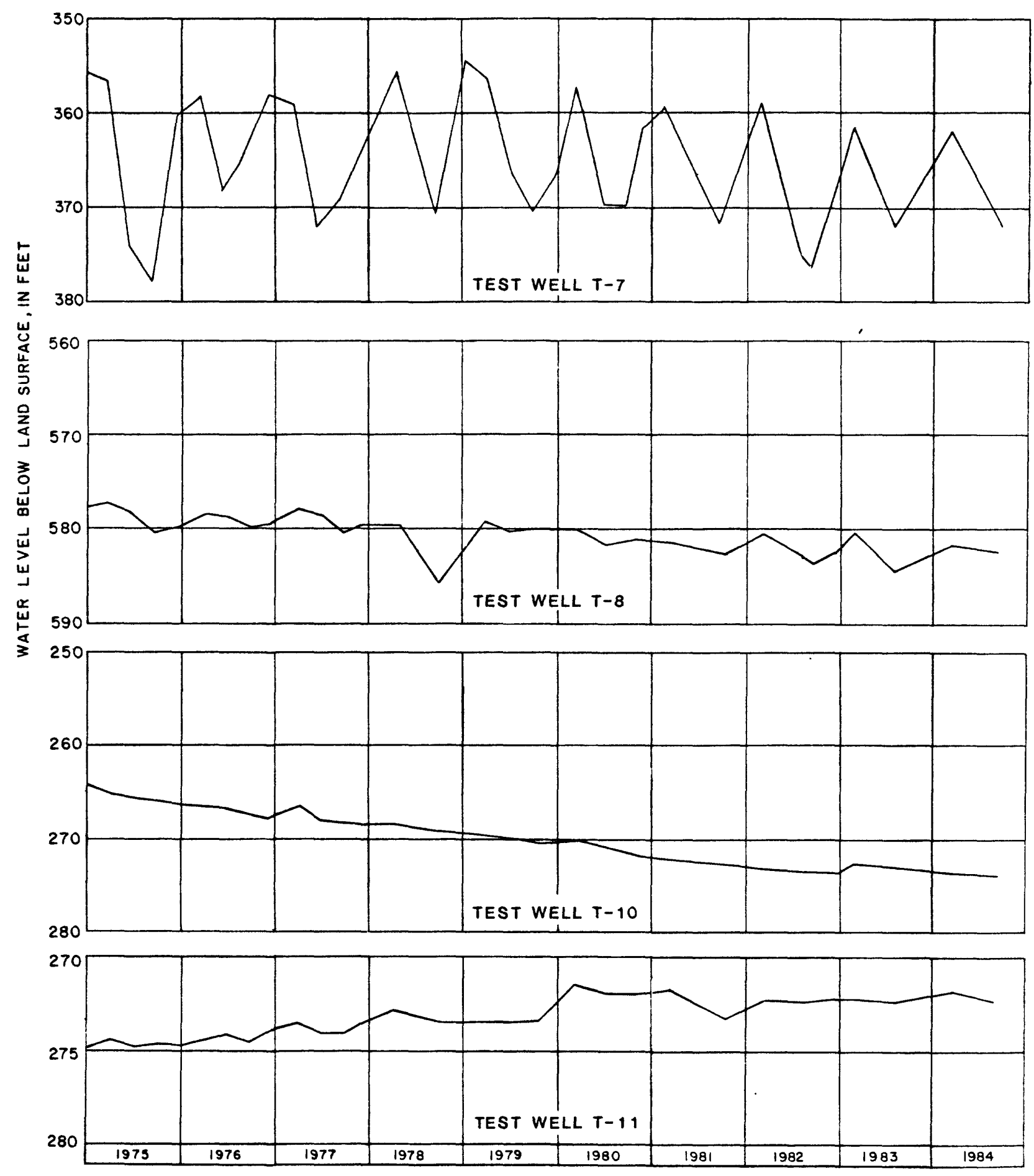

Figure 10.--Water levels in test wells $T-7, T-8, T-10$, and $T-11$. 
Semiannual depth-to-water measurements were made in 37 boreholes in 1984 (table 4). Two (B-37 and B-42) of the four boreholes west of the Post Headquarters continued to show a rise in water level. Water-level declines were observed in all of the boreholes less than $2 y_{2}$ miles east of the Post Headquarters well field.

Table 4.-Depth to water in boreholes, Post Headquarters and adjacent areas, 1984

\begin{tabular}{|c|c|c|c|}
\hline $\begin{array}{l}\text { Borehole } \\
\text { number }\end{array}$ & Location & $\begin{array}{l}\text { Winter } 1984 \\
\text { (feet below } \\
\text { land surface) }\end{array}$ & $\begin{array}{l}\text { Summer } 1984 \\
\text { (feet below } \\
\text { land surface) }\end{array}$ \\
\hline $\begin{array}{l}\text { B-2 } \\
\text { B-3 } \\
B-4 \\
B-5 \\
B-6\end{array}$ & $\begin{array}{l}\text { 22S.5E.28.124 } \\
\text { 22S.5E.28.142 } \\
\text { 22S.5E.28.233 } \\
\text { 22S.5E.33.223 } \\
23 S .5 E .01 .113\end{array}$ & $\begin{array}{l}194.56 \\
201.82 \\
196.33 \\
187.68 \\
133.78\end{array}$ & $\begin{array}{l}195.53 \\
202.42 \\
196.29 \\
187.51 \\
133.79\end{array}$ \\
\hline $\begin{array}{l}B-9 \\
B-10 \\
B-13 \\
B-14 \\
B-15\end{array}$ & $\begin{array}{l}22 S .5 E .21 .211 \\
22 S .5 E .19 .414 \\
22 S .5 E .08 .141 \\
22 S .5 E .03 .221 \\
22 S .5 E .05 .242\end{array}$ & $\begin{array}{l}225.08 \\
306.20 \\
244.13 \\
112.39 \\
174.35\end{array}$ & $\begin{array}{l}225.14 \\
307.08 \\
244.46 \\
112.51 \\
174.46\end{array}$ \\
\hline $\begin{array}{l}B-16 \\
B-17 \\
B-18 \\
B-20 \\
B-23\end{array}$ & $\begin{array}{l}21 S .5 E .34 .213 \\
21 S .5 E .33 .242 \\
21 S .5 E .23 .134 \\
22 S .4 E .14 .134 \\
22 S .5 E .16 .111\end{array}$ & $\begin{array}{l}109.45 \\
111.68 \\
104.57 \\
349.00 \\
223.83\end{array}$ & $\begin{array}{l}109.57 \\
111.81 \\
104.63 \\
349.38 \\
225.23\end{array}$ \\
\hline $\begin{array}{l}B-26 \\
B-27 \\
B-28 \\
B-30 \\
B-31\end{array}$ & $\begin{array}{l}21 S .6 E .32 .114 \\
21 S .6 E .17 .314 \\
21 S .5 E .02 .341 \\
20 S .5 E .23 .213 \\
20 S .6 E .29 .123\end{array}$ & $\begin{array}{r}141.06 \\
119.76 \\
135.35 \\
89.69 \\
123.22\end{array}$ & $\begin{array}{r}141.26 \\
119.94 \\
140.39 \\
89.58 \\
123.44\end{array}$ \\
\hline $\begin{array}{l}B-34 \\
B-36 \\
B-37 \\
B-38 \\
B-39\end{array}$ & $\begin{array}{l}21 S .5 E .01 .221 \\
22 S .4 E .01 .323 \\
22 S .4 E .11 .344 \\
20 S .6 E .11 .234 \\
21 S .6 E .02 .142\end{array}$ & $\begin{array}{l}126.35 \\
212.08 \\
390.50 \\
129.78 \\
156.29\end{array}$ & $\begin{array}{l}126.37 \\
212.26 \\
389.79 \\
129.85 \\
156.38\end{array}$ \\
\hline
\end{tabular}


Table 4.-Depth to water in boreholes, Post Headquarters and adjacent areas, 1984 - Concluded

\begin{tabular}{llll}
\hline $\begin{array}{l}\text { Borehole } \\
\text { number }\end{array}$ & Location & $\begin{array}{l}\text { Winter 1984 } \\
\text { (feet below } \\
\text { land surface) }\end{array}$ & $\begin{array}{l}\text { Summer 1984 } \\
\text { (feet below } \\
\text { land surface) }\end{array}$ \\
\hline B-40 & 21S.6E.26.142 & 188.50 & 188.62 \\
B-42 & 22S.4E.11.444 & 373.06 & 371.90 \\
B-46 & 21S.5E.27.113 & 135.95 & 136.01 \\
B-47 & 22S.5E.08.334 & 274.20 & 274.41 \\
B-48 & 22S.6E.31.322 & 204.63 & 204.58 \\
B-49 & 22S.5E.09.113 & 201.18 & 200.54 \\
B-50 & $22 S .5 E .07 .242$ & 306.39 & 306.63 \\
B-51 & $22 S .5 E .26 .312$ & 146.44 & 146.42 \\
B-52 & $22 S .5 E .09 .113$ & 210.75 & 210.97 \\
B-54 & $22 S .5 E .16 .111$ & 228.80 & 229.09 \\
B-55 & $22 S .5 E .09 .113$ & 214.83 & 214.90 \\
B-56 & $22 S .5 E .30 .424$ & 276.25 & 276.34 \\
\hline
\end{tabular}




\section{Chemical Quality}

Seven water samples from supply wells were collected for major chemicalconstituent analyses in 1984 (table 5). Five water samples from test wells were collected for major chemical-constituent and trace-element analyses in 1984 (table 6). Seven water samples from supply wells were collected for radiochemical analyses (table 7). Long-term specific conductance for water from the Post Headquarters supply wells is shown in figures 7,8, and 9. Monthly $\mathrm{pH}$ measurements and specific conductance are shown in figures $11-13$. 
Supply Well 10A
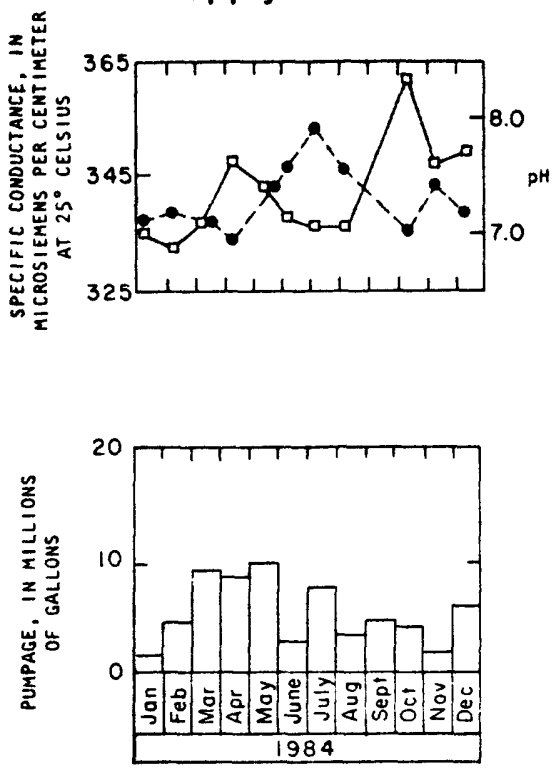

Supply Well 11
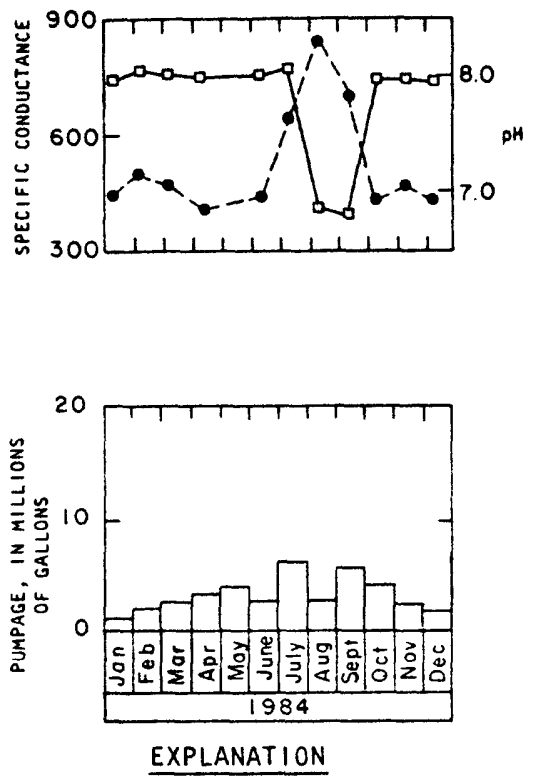

Supply Well 13
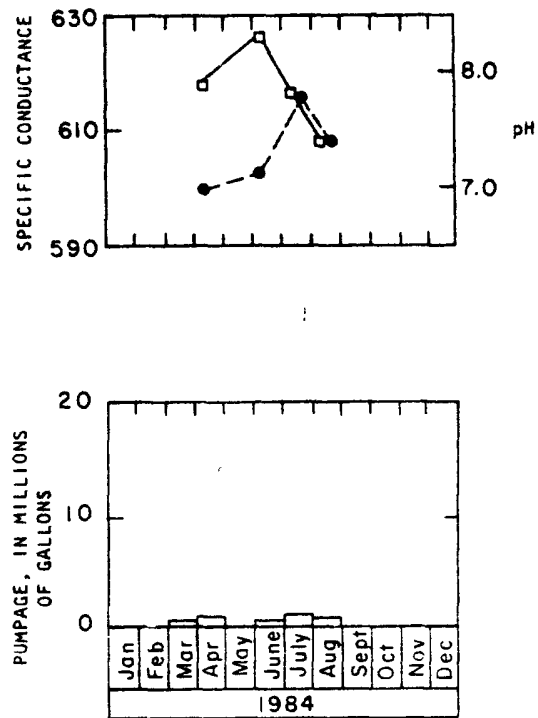

$\rightarrow-\rightarrow \mathrm{PH} \quad \mathrm{SPECIFIC}$ CONDUCTANCE

Figure 11.--Monthly specific conductance, $\mathrm{pH}$, and pumpage for supply wells 10A, 11, and 13 .

Supply Well 16
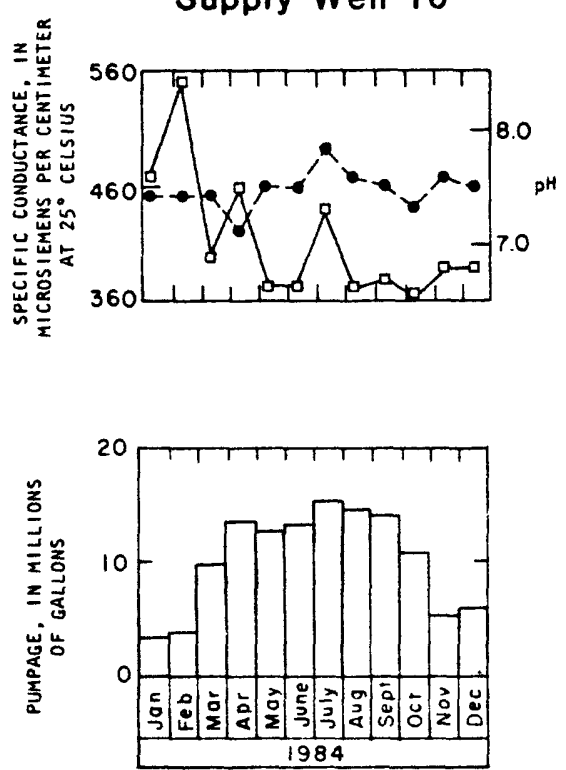

Supply Well 17
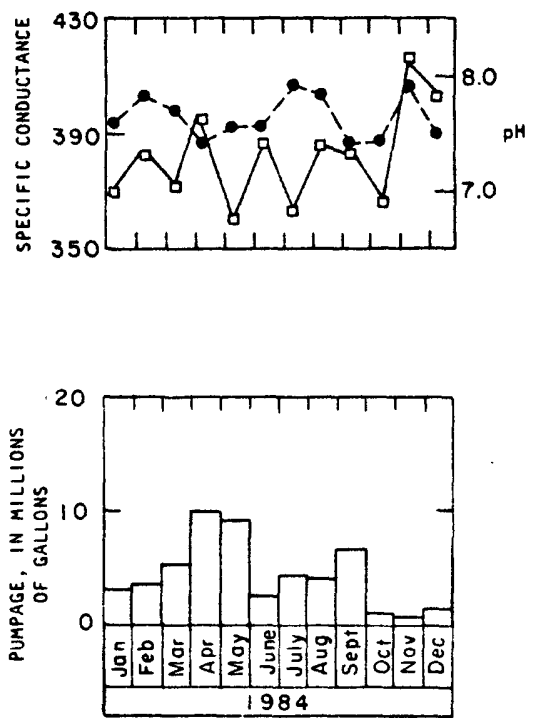

EXPLANATION
Supply Well 18

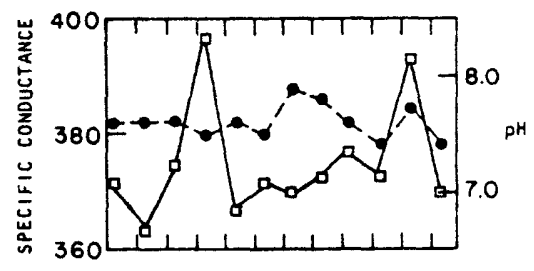

$\longrightarrow$ PH $\longrightarrow$ SPECIFIC CONDUCTANCE

Figure 12.--Monthly specific conductance, $\mathrm{pH}$, and pumpage for supply wells 16,17 , and 18 . 


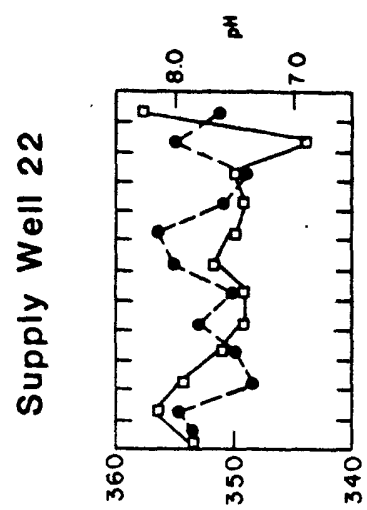

JJNVIJNONOJ JIAIJJAS

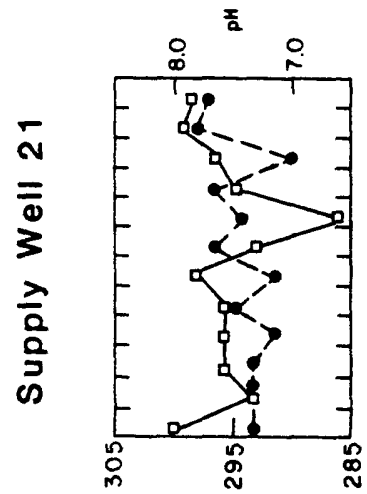

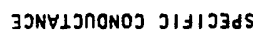

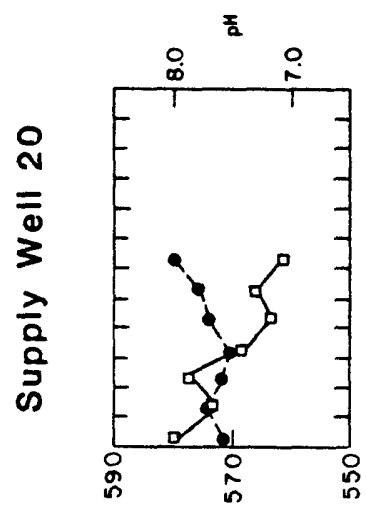

JJNVIJTONOJ JIJIJJdS

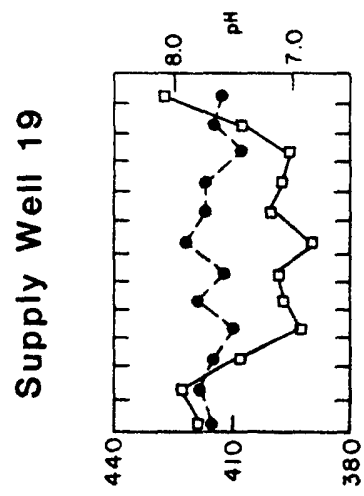

SחISTJJ. 5216

YIIJWILNGJ Y3d SNJWIISOYJIW NI JJNHIJNONOJ JIdIJJdS
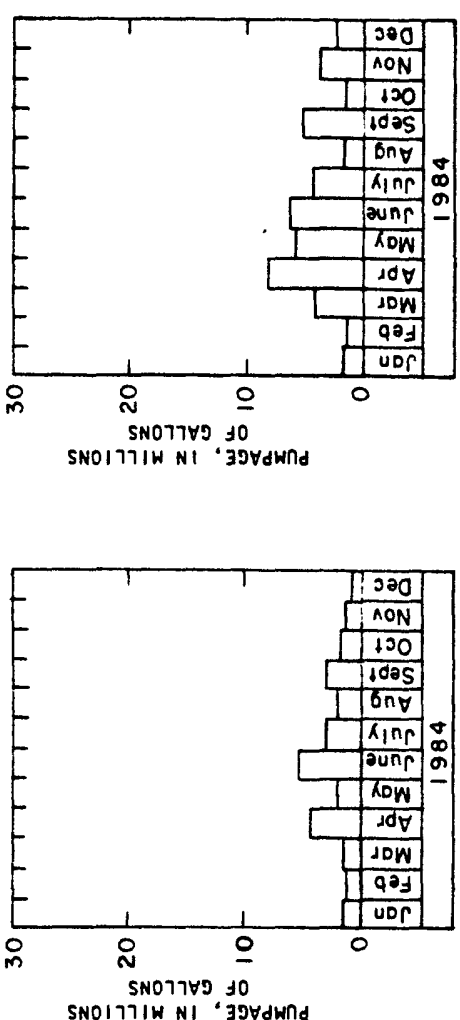

要

ก

亭

$\bar{\sim}$

i

i

$\frac{n}{3}$

$\frac{2}{\frac{2}{2}}$

เо

0
0
0
0
$\bar{E}$
0

एँ

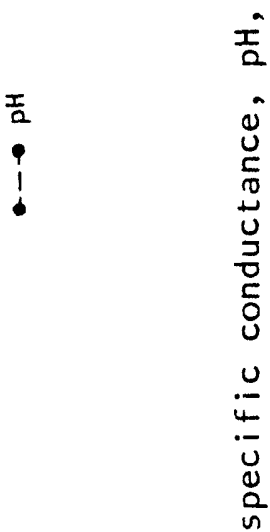

I.
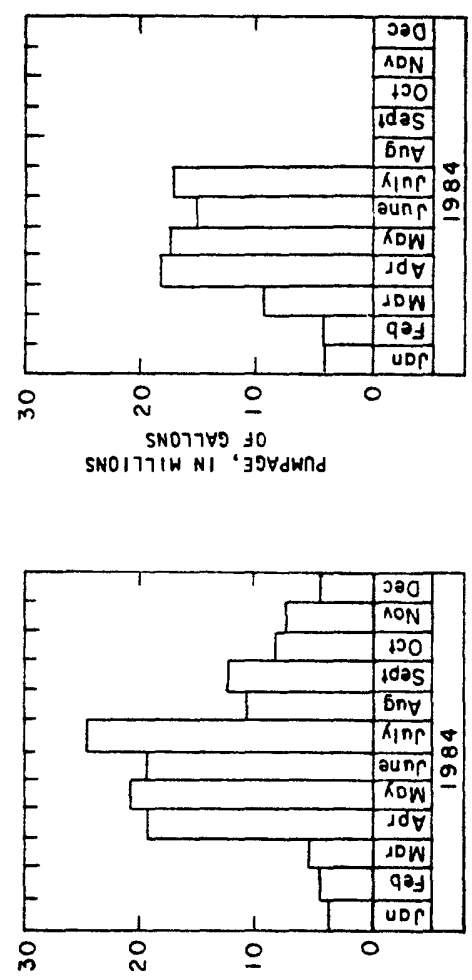

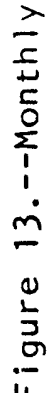

SNOาาษ

SNO17רIW NI "3פYdWnd 


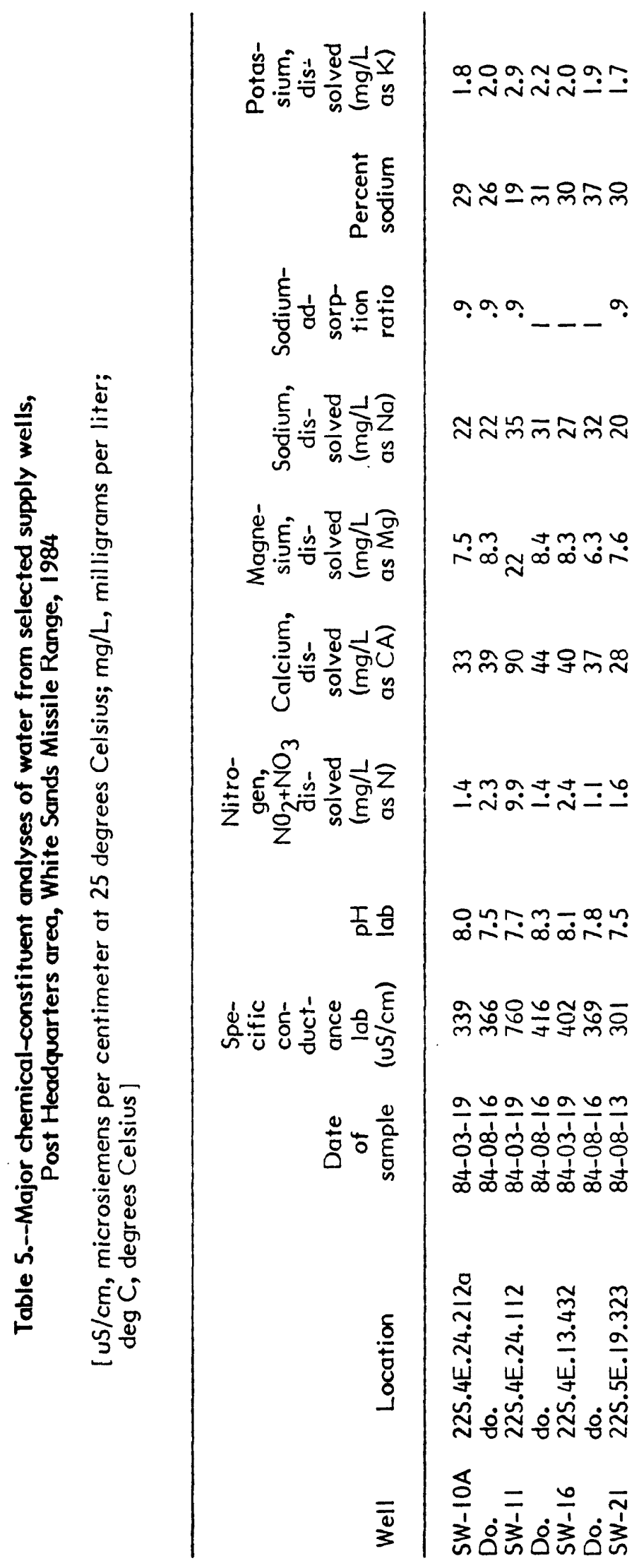

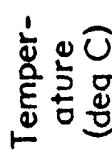

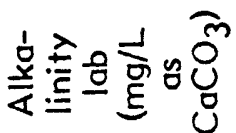

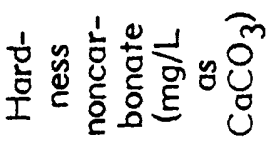

혼

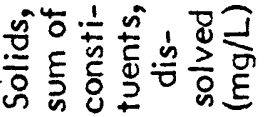

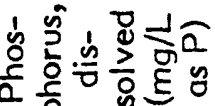

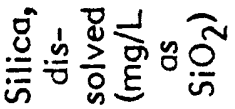

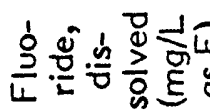

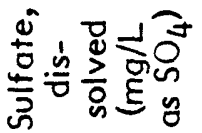

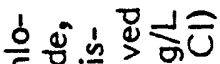

ट

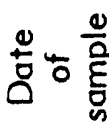

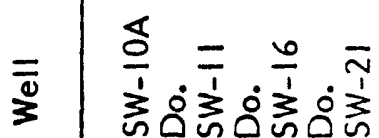




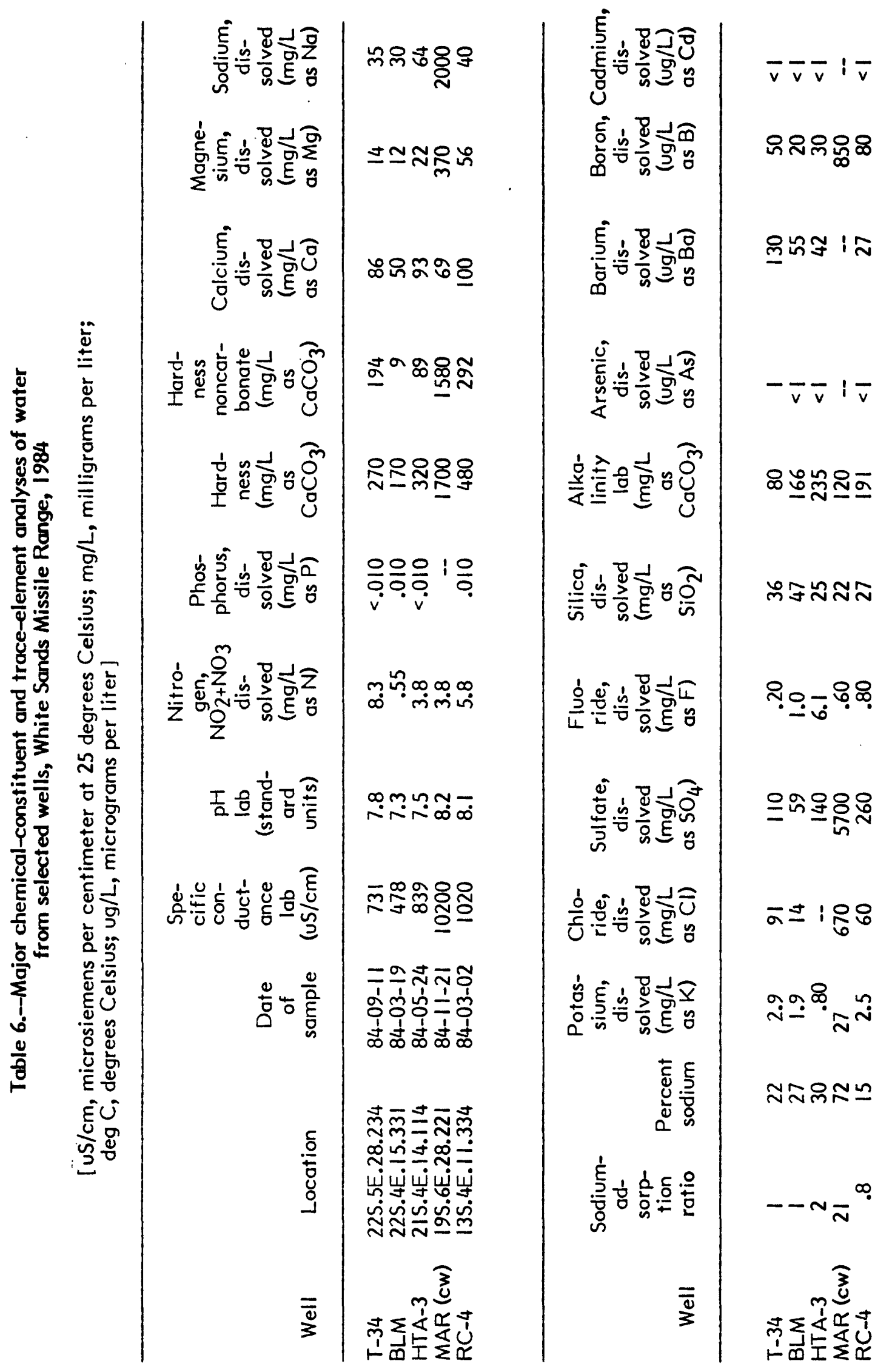




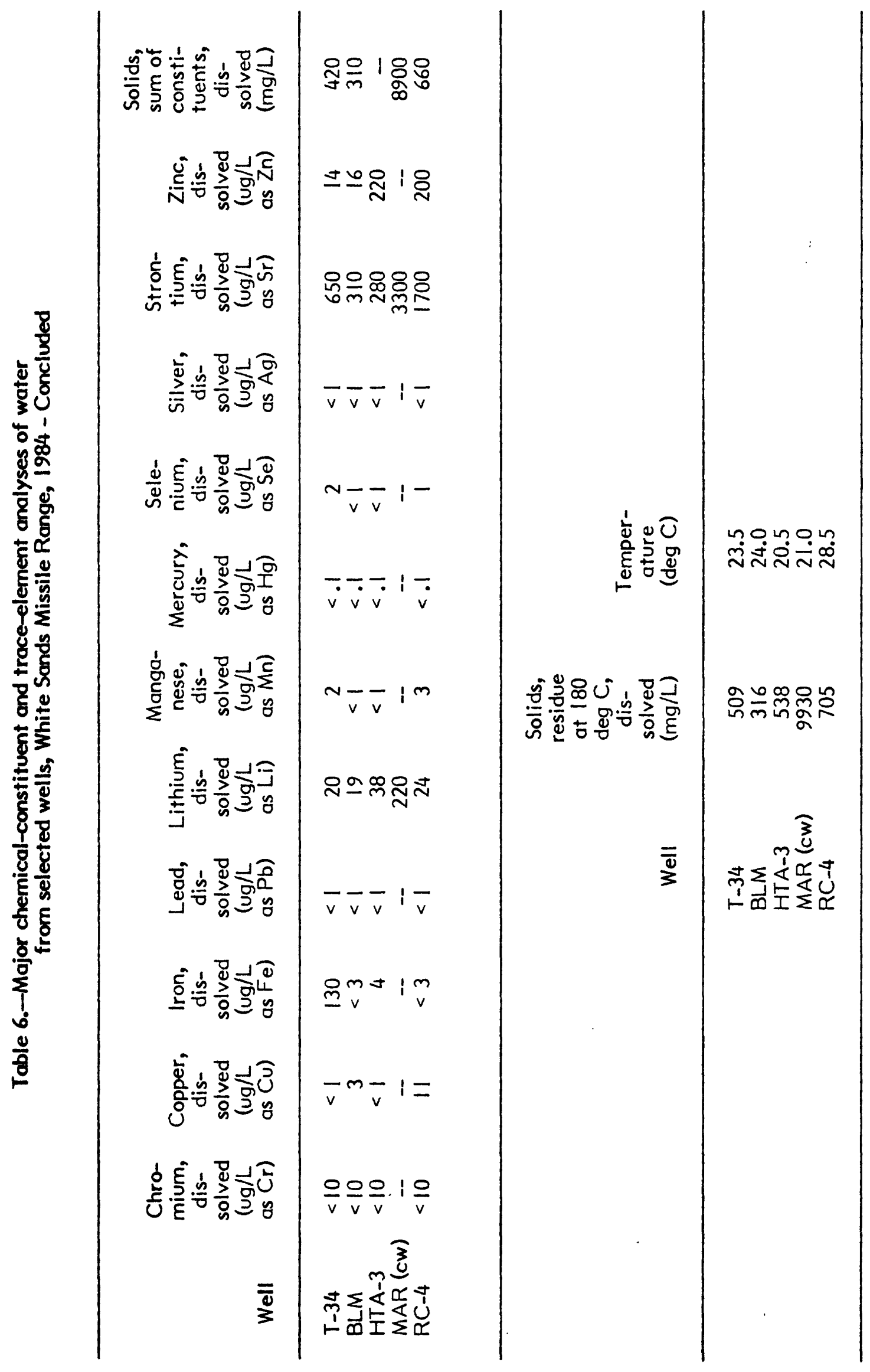




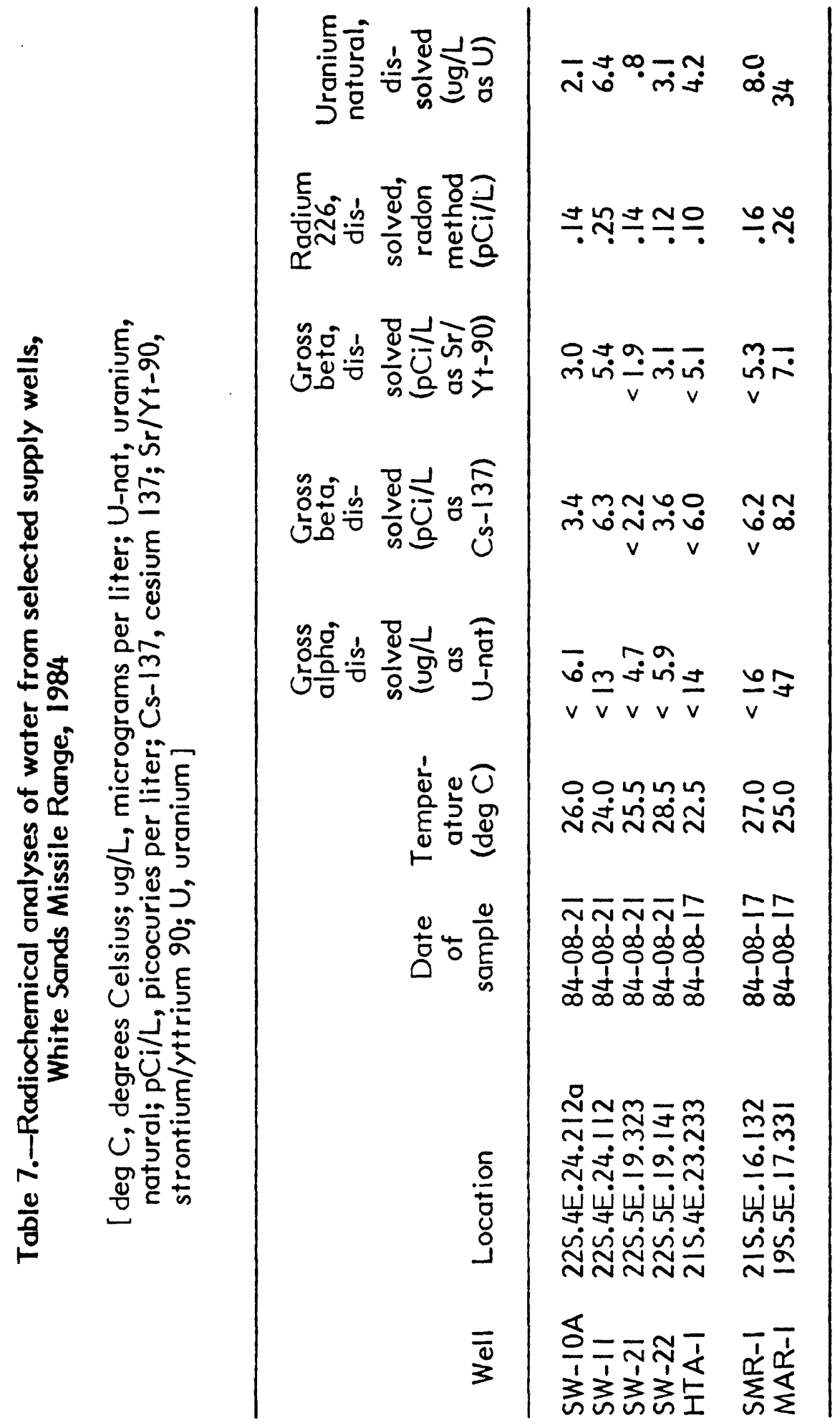




\section{REFERENCES}

Cooper, J. B., 1970, Summary records of supply wells and test wells in the Post Headquarters area, White Sands Missile Range, New Mexico: U.S. Geological Survey open-file report, $202 \mathrm{p}$.

1973, Summary records of test and supply wells in Range Areas, White Sands Missile Range, New Mexico: U.S. Geological Survey open-file report, 132 p.

Kelly, T. E., 1973, Summary of ground-water data at Post Headquarters and adjacent areas, White Sands Missile Range: U.S. Geological Survey open-file report, 66 p.

Myers, R. G., 1984, Test wells T21, T22, and T25, White Sands Missile Range, Doña Ana County, New Mexico: U.S. Geological Survey Open-File Report 83-77I, 30 p. 